\title{
Offering branded remanufactured/recycled products: at what price?
}

\author{
Leila Hamzaoui-Essoussi ${ }^{1}$ and Jonathan D Linton ${ }^{2 *}$
}

\author{
* Correspondence: \\ Linton@UOttawa.ca \\ ${ }^{2}$ Power Corporation for the \\ Management of Technological \\ Enterprises, University of Ottawa, 55 \\ Laurier E, Ottawa K1N 6 N5, Ontario, \\ Canada \\ Full list of author information is \\ available at the end of the article
}

\begin{abstract}
This paper investigates the impact of product category, perceived risk, and brand name on consumers' willingness to pay (WTP) for greener (recycled/remanufactured) products. Results provide an understanding on how consumers differentiate between types of products when stating their WTP. The findings suggest that WTP for greener versus branded greener or new products varies with product category. For paper, toner cartridges, and cell phones, brand effects are apparent. However, for cameras and printers brand does not appear to counterbalance perceived risk. As the importance of brand is a function of product category and is significantly related to WTP, original equipment manufacturers (OEMs) should carefully consider this relationship for their products before making decisions on the use of brand as a part of remanufacturing/recycling strategy.
\end{abstract}

Keywords: Brand name; Willingness to pay; Remanufacturing

\section{Introduction}

The relationship between brand and willingness to pay (WTP) for products that are 'greener', because they are made of recycled content and/or utilize parts from postconsumer products (i.e., remanufactured products), is considered. Remanufacturing is more environmentally friendly and inherently greener as it recaptures the value of a material that was already engineered for product use. Remanufacturing not only captures the value of the engineered materials but also the physical form of the product through the use of parts and assemblies that are either in or can be upgraded to a like-new or better than new condition. While environmental marketing has been considered for decades, there is limited research on recycled and remanufactured products in the marketing literature. This paper helps close this gap.

Production by industry, consumption patterns, and behavior of the consumers are causing environmental concerns [1]. Marketers recognize that responding to environmental degradation can be done through the introduction of green products [2]. Although greener products remain a niche market [3], firms are developing products and processes that are both economically and environmentally attractive [4-6]. Simultaneously, legislation and regulations requiring the reuse of material and end of product life take-back have been put in place [7-10], and advances in operations and manufacturing management have enabled the reuse of material and part contents for existing products [11]. Moreover,

(c) 2014 Hamzaoui-Essoussi and Linton; licensee Springer. This is an Open Access article distributed under the terms of the Creative Commons Attribution License (http://creativecommons.org/licenses/by/4.0), which permits unrestricted use, distribution, and reproduction in any medium, provided the original work is properly credited. 
consumers' growing concerns for environmental issues are leading to new market opportunities, justifying an increased interest in product remanufacturing [12].

In this context, the manufacturing and operational issues associated with the incorporation of reused and recycled materials are increasingly addressed by both academe and practice [13-18]. While the topic of green marketing is well researched [19,20] and shows that consumers express strong concerns for the environment and for recycling [21,22], the influence of consumers' attitudes on their consumption practices with recycled and remanufactured products has yet to be explicitly studied. Recycled and remanufactured products offer an under-explored new subfield to the new product development and marketing literature.

Consumers often perceive recycled and remanufactured products to be inferior to new conventional products $[23,24]$. This research shows that a lack of familiarity with the use of recycled/used materials in some products makes consumers less willing to pay premium prices for products like refurbished tires. This highlights how the perceived functional risk associated to recycled or remanufactured products is considered due to its influence on the WTP for a product [25]. Whether this risk can be addressed by using risk reduction strategies such as brand names - to positively influence consumer attitude towards WTP for recycled or remanufactured products still needs further study. Brands reduce perceived risk by acting as a proxy for product quality [26,27] and can command price premiums [28]. However, the role of brands has not yet been considered for recycled and remanufactured products. This is important as it helps determine if consumer assessment of quality and risk can be counterbalanced by the presence of a brand when the consumer considers greener (recycled and remanufactured) products. Therefore, the focus is on the impact of original equipment manufacturer (OEM) brand on the relative attractiveness of greener products - i.e., consumers' WTP for these products.

This study examines consumers' WTP price premiums for branded recycled/ remanufactured products versus conventional products. Two specific objectives are addressed: (1) the impact of product category and its related perceived risk on WTP for recycled/remanufactured products and (2) the impact of the brand name on WTP for these products.

\section{Background}

Sustainable development requires 'sustainable marketing' as marketing efforts must focus not only on competition and product survival but also to protect the environment for future generations [19,29]. In response to the concern over environmental degradation, marketers understand the importance of introducing products that involve recycling, packaging reduction, re-consumption, dematerialization, use of sustainable raw materials, increased product durability, improving repairability, post-consumer use, compostable products and packaging, and lowering environmental impact during use [19,29-31]. Success requires understanding tradeoffs between product quality and functionality with green attributes as well as how much consumers are willing to pay for 'green' products.

\section{Greener products: recycled and remanufactured products}

Sustainability initiatives, more specifically remanufacturing, are becoming more prevalent $[12,14,32,33]$. Public and government pressure motivates firms to adopt remanufacturing 
and to maximize profits from product returns [34]. For example, ReCellular Inc. processes more than 400,000 returned cell phones every month, of which nearly $70 \%$ are remanufactured and resold [35]. Products such as personal computers, fridges, mobile phones, photography equipment, toner cartridges, and copiers are already remanufactured by OEMs [12].

Remanufactured products undergo 'the process of disassembling, cleaning, inspecting, repairing, replacing, and reassembling the components of a part or product to like-new conditions' ([36], p.35). Because products are restored to a like-new condition, remanufacturing is characteristically distinct from repair or reuse activities - remanufactured components keep their original function. Recycling does not capture the value associated with the shape of a part or product but only the residual value of the material. For a material like aluminum, there is no difference in quality between a virgin and recycled material. However, for other materials such as paper and plastic, recycling processes substantially reduce material quality. Consequently, products made of recycled materials may be inferior to products made of virgin materials and thus offer lower product performance. Moreover, consumers may lack knowledge about remanufacturing or even confuse remanufactured products with pre-owned/used products [21,22], further affecting perceptions of product quality.

Mobley et al. [23] found that recycled products are considered eco-friendly and are positively evaluated by consumers. An increased demand for these products and green marketing is driven by rising consumer awareness and consciousness about the environment [37] and by growing environmental crises. Since the 1970s, the environment is an increasingly important construct within the marketing literature. Sensitivity to environmental issues shifts consumer behavior towards the growth and diffusion of green marketing and other ecologically conscious behavior - including preference for greener firms, increased demand for greener products, and greater acceptance of recycling [20,23]. While environmental awareness and concern have increased, an attitude-behavior gap still exists [20]. While there is a general tendency of consumers to be prepared to pay more for environmentally friendlier products [38], there is still skepticism about paying premiums as consumers have residual concerns regarding product functionality and performance $[21,22]$. Not much is known about consumers' attitudes and WTP for recycled and remanufactured products. Consequently, the link between perceived quality, perceived risk, and consumers' willingness to pay for recycled/remanufactured product is considered.

\section{Perceived quality, perceived risk, and willingness to pay}

Perceived product performance is a significant barrier to the selection for consumption of environmentally sustainable products [39], which in turn influences consumers' WTP for these products $[38,40-42]$.

It is often assumed that one's WTP, the maximum amount of money that a consumer will pay for a good [42], corresponds with perception of relative quality level. A lower perceived quality of remanufactured products is associated with a reduced WTP for remanufactured products [43]. Past research suggests that consumers often do not fully understand and trust the processes and procedures involved in remanufacturing - that is, remanufactured products are seen as inferior in quality and have a lower value than new products $[24,44]$. The actual level of quality in remanufactured products may even 
exceed that of new products $[21,22,45]$. The WTP for products with remanufactured or recycled components and materials appears linked to perceptions of quality and the risk that reflect uncertainty of the actual levels of quality. WTP also relates to the perceived potential outcomes of product use.

Consumers differ with respect to the risk level they are willing to incur in a given situation [46]. The concept of risk consists of (1) uncertainty of outcome, (2) importance of the negative consequences associated with the outcome [47], and (3) perceived severity of negative consequences of the outcome [48]. Both perceived uncertainty of outcomes and the level of negative consequences may differ from situation to situation [49]. Moreover, many studies show that consumers perceive risk differently, and their risk-reducing behavior depends very much on the product class [50-52]. Consumers' perceived quality and WTP for recycled/remanufactured products are influenced by the perceived ambiguity inherent in the recycling or remanufacturing process $[23,44]$. If the evaluation of a recycled/remanufactured product is influenced by the type of product and by the perceived risk associated to it, consumers' WTP will vary with the product category. Therefore:

H1: Consumers' WTP a premium price for recycled/remanufactured products differs between product categories.

\section{Brand name and willingness to pay}

Product and brand management studies show the effect of risk aversion on consumer decision-making and willingness to purchase [51,53]. Zeithaml [54] and Bauer [55] suggest that consumers use extrinsic cues to form perceptions of product quality (or benefits) and perceptions of monetary sacrifice (or cost) to determine product value [52]. The most commonly studied extrinsic cues are price and brand [51].

A brand is 'a name, term, sign, symbol, or design, or a combination of them, that is intended to identify the goods and services of one seller or a group of sellers and to differentiate them from those of competitors' ([56], p.443). Researchers view a brand name as a summary construct $[57,58]$ for quality. That is, consumers often infer product quality based on brand and pay premium prices for branded products, because brands are perceived to offer quality and reduced risk of failure [51]. Brands play multiple roles in consumer decision-making [59]. Brands help alleviate consumers' feelings of threat and ambiguity of novel situations that make them reluctant to try new products. Consumer perception of risk is based on untried products being uncertain and unknown compared to established products and brands [60]. Quality uncertainty, especially in the presence of risk aversion, results in consumers searching for additional information regarding product quality prior to making a purchase [61,62].

Aaker [26] suggests that, all else being equal, strong brands are associated with high quality. Pickett-Baker and Ozaki [39] show that consumers associate well-known brands with effective products. Furthermore, the perceived risk of whether a product will perform as expected is lower for a well-known and respected brand than a less well-known brand [63]. Brands are also seen as credible signals as they embody the cumulative effect of prior marketing-mix strategies and activities (e.g., advertising, product development, and pricing). The notion that credibility is the sum of prior behaviors is referred to as 'reputation' in the information economics literature [64]. The literature also considers 
the importance of brand credibility under consumer uncertainty [65-67]. Brand credibility is the believability of the product information contained in a brand. This requires that consumers perceive a brand to have the ability (expertise) and willingness (trustworthiness) to deliver as promised [65]. This aspect of a brand is relevant as using the brand name of established product manufacturers to provide new conventional products on the market, not brand names of specific remanufacturing companies, is being considered. Moreover, Michaud and Llenena [12] suggest that consumers are more confident with a remanufactured product offered by an OEM well known for conventional products rather than by unknown third parties.

According to Subramanian and Subramanyam [68], remanufacturer identity significantly explains price differentials for remanufactured electronic products: consumers pay higher prices for products remanufactured by OEMs than for those remanufactured by third parties. Consumers show purchase preferences for green products offered by established brands [69]. The cost of brand development leads some companies to use existing brands for the introduction of new products, including green products. Aaker and Keller [70] (1990) indicate that there are risks associated with extending a brand name. A lower perceived quality for recycled/remanufactured products may have a negative impact on a brand. This is critical to note as OEMs rarely remanufacture products [71].

Branding can signal product position when there is consumer uncertainty about a product. If consumers perceive the brand as having the ability and willingness to deliver what is expected, then expected quality level will increase and perceived risk will decrease, leading to an overall increase in expected utility [27]. Consequently, it is worth examining the relevance of brand to WTP for recycled/remanufactured products as lower perceived quality of recycled/remanufactured products is assumed to lead to reduced WTP for these products [43]. But as strong brands command great price premiums [28,72,73], brands are expected to influence perceived quality and perceived risk related to greener (recycled/ remanufactured) products, and thus consumers' WTP for these products.

H2: Consumers' WTP a premium price for branded recycled/remanufactured products will be higher than for unbranded recycled/remanufactured products.

H3: Consumers' WTP a premium price for unbranded recycled/remanufactured products will be lower than for branded new products.

H4: Consumers' WTP a premium price for branded new products will be higher than for branded recycled/remanufactured products.

\section{Methods}

Five product categories were chosen: personal electronics (cell phone, single-use camera), home or business electronics (toner cartridge, printer), and paper. The selection criteria were based on the different degrees of perceived risk associated to these categories and on the varying degrees of hedonic and functional dimensions related to product consumption (personal electronics entail more hedonic than functional dimensions than home office electronics or paper). The choice of product categories was guided by current products' availability in a remanufactured form. These products are commonly used by younger adults that are likely to have knowledge of remanufactured products and high levels of environmental consciousness. Each subject was exposed to information on all five products. 
For each category, the most respected brand names were utilized. This selection was based on interviews with 14 students regarding brand awareness and brand knowledge regarding brands available on the Canadian market. Brand names of OEMs offering conventional products were chosen in order to test the effect of known brand names on perceived quality and WTP for recycled/remanufactured products. The selected brands were as follows: Domtar - paper, LG - cell phones, NEC - printers, Konica - single-use cameras, and Epson - toner cartridges.

A survey on WTP for recycled and remanufactured products was developed (see Additional file 1). The first section considered constructs relating to familiarity [74] and involvement with recycling [75], perceived product quality, environmental knowledge [76], and perceived risk [77] related to recycled/remanufactured products (in general and not for each product category). The second section was based on [15,25] and considered willingness to pay for recycled/remanufactured products, branded recycled/remanufactured products, and branded new products. For each product category, respondents were given the average price of the conventional version of the product and then asked to state their willingness to pay more, the same, or less than that regular amount. The respondents indicated the increase or decrease in their WTP. Finally, a measure of environmental consciousness [76] and demographic information is collected.

A two-phase pilot test was conducted to assess the survey. Four students and three academicians completed the survey, reviewing it for content appropriateness and clarity. Only minor changes to the format of the instrument were made after this pilot test. Next, the survey was deployed to targeted respondents - undergraduate management students. Hazen et al. [44] indicate that university students often have ample experience with recycled/remanufactured products and thus represent potential consumers of these products. Others suggest that younger adults are more knowledgeable about remanufactured items than older adults $[78,79]$. Furthermore, the product categories considered are commonly used by university students. Consequently, they are a suitable target sample.

The survey was offered in both English and French to 550 students at a large Canadian university (in 2nd and 3rd year undergraduate classes); 359 completed surveys were completed. Three-hundred and twenty-two surveys were usable. SPSS was utilized for descriptive statistics and hypotheses testing.

The final sample $(n=322)$ was $52 \%$, and $88.9 \%$ of the respondents were between 18 and 24 years old. Annual family income was under $\$ 49,000(35.8 \%)$, in the range of $\$ 50,000$ to $\$ 99,000$ (28.3\%), and more than $\$ 100,000$ (35.8\%) for respondents.

\section{Results}

Familiarity with recycling, environmental knowledge, involvement with recycled products, environmental consciousness, and perceived risk (five-point Likert scales) were considered.

The respondents are moderately familiar with recycling and have a good general environmental knowledge (Table 1). The respondents consider themselves as involved with recycling and having a high level environmental consciousness. The perceived risk linked to recycled/remanufactured products suggests that recycled/remanufactured products are considered to be somewhat risky. 
Table 1 Means for environmental variables and perceived risk

\begin{tabular}{llll}
\hline Factors & Mean & Standard deviation & Sample size \\
\hline Familiarity with recycled products & 2.58 & 0.92 & 312 \\
Environmental knowledge & 3.36 & 0.79 & 318 \\
Involvement with recycling & 3.58 & 0.70 & 317 \\
Environmental consciousness & 3.99 & 0.65 & 318 \\
Perceived risk & 2.52 & 0.85 & 317 \\
\hline
\end{tabular}

Recycled paper is considered as a product of good quality, followed by remanufactured toner cartridge, remanufactured printers and cell phones, and with reused single-use cameras following behind (Table 2). Overall, these greener versions of products are considered to be of above average quality, although differences exist between product categories.

Analysis of consumers' willingness to pay was conducted based on the comparison of (1) branded recycled products versus unbranded recycled products, (2) recycled products versus branded products, and (3) branded products versus branded recycled products, for each product category.

H1: Consumers' WTP a premium price for recycled/remanufactured products differs between product categories - supported.

Table 3 summarizes the differences in consumers' WTP between the product categories. The first notable difference is between recycled paper and the other product categories: paper has the most people willing to pay a price premium and the smallest number of consumers expecting a price discount. Cell phones have the most people willing to pay a discounted price. Interestingly, printers and toner cartridges present the second most people willing to pay a discounted price; and toner cartridges the least people willing to pay a premium price. Consumers' WTP a discounted or a premium price varies with product category.

H2: Consumers' WTP a premium price for branded recycled/remanufactured products will be higher than for unbranded recycled/remanufactured products - partially supported.

Three categories (Table 4) show a statistically significant difference in WTP.

Table 4 shows how branded recycled paper is described as being more valuable than recycled paper. Similar results apply for cell phones and the toner cartridges. In some cases, it is worth branding recycled products, but not in all cases. The difference for single-use cameras, printers, and tires is insignificant - i.e., consumers will not always pay extra for branded products. As only one brand is considered, comments cannot be made relating to the importance of specific brands.

H3: Consumers' WTP a premium price for unbranded recycled/remanufactured products will be lower than for branded new products - partially supported.

Table 2 Perceived quality of recycled/remanufactured products

\begin{tabular}{llll}
\hline Perceived quality of recycled/remanufactured & Mean & Standard deviation & Sample size \\
\hline Paper & 3.70 & 0.9 & 319 \\
Toner cartridges & 3.61 & 1.02 & 320 \\
Printers & 3.42 & 1.08 & 320 \\
Cell phones & 3.41 & 1.12 & 320 \\
Single-use cameras & 3.12 & 1.08 & 320 \\
\hline
\end{tabular}


Table 3 Summary of differences in willingness to pay

\begin{tabular}{|c|c|c|c|c|c|}
\hline $\begin{array}{l}\text { Willingness } \\
\text { to pay }\end{array}$ & $\begin{array}{l}\text { Recycled } \\
\text { paper }\end{array}$ & $\begin{array}{l}\text { Reused } \\
\text { camera }\end{array}$ & $\begin{array}{l}\text { Remanufactured } \\
\text { cell phone }\end{array}$ & $\begin{array}{l}\text { Remanufactured } \\
\text { printer }\end{array}$ & $\begin{array}{l}\text { Remanufactured } \\
\text { toner }\end{array}$ \\
\hline \multicolumn{6}{|l|}{ Decreased WTP } \\
\hline $0.10 \%$ to $0.50 \%$ & $12(2.8 \%) 5.4$ & 19 (6.0\%) 8.1 & $43(13 \%) 19.5$ & 30 (9.4\%) 14.6 & $28(8.7 \%) 12.7$ \\
\hline $0.60 \%$ to $0.80 \%$ & $32(10 \%) 23.9$ & 41 (13\%) 30.7 & 65 (20\%) 47.1 & $56(18 \%) 41.4$ & $64(20 \%) 47.2$ \\
\hline $0.81 \%$ to $0.99 \%$ & 45 (14\%) 41.1 & 70 (22\%) 63.5 & $71(22 \%) 62.4$ & 79 (25\%) 70.0 & $72(22 \%) 63.5$ \\
\hline \multicolumn{6}{|l|}{ Same WTP } \\
\hline 1.00 & $144(45 \%) 144$ & $140(44 \%) 140$ & 99 (31\%) 99 & 113 (35\%) 113 & 123 (38\%) 123 \\
\hline \multicolumn{6}{|l|}{ Increased WTP } \\
\hline $1.01 \%$ to $1.20 \%$ & $84(26 \%) 91.81$ & 46 (14\%) 50.8 & 36 (11\%) 39.7 & 37 (12\%) 40.4 & $33(10 \%) 36.2$ \\
\hline $1.21 \%$ to $1.50 \%$ & $3(0.9 \%) 3.8$ & $3(0.9 \%) 3.8$ & $6(1.9 \%) 7.9$ & $4(1.2 \%) 5.4$ & $1(0.3 \%) 1.25$ \\
\hline Total respondents & 320 & 319 & 320 & 319 & 321 \\
\hline
\end{tabular}

Number of respondents at each level, percentage, and sum for each reported level.

Table 5 indicates that the WTP for paper is not a function of newness. It seems that 'saving a tree' matters to many people and is considered when purchasing paper. Recycled paper is so commonplace that it is seen as holding no disadvantage in relation to virgin pulp. In fact, recycled paper is often preferred. Branding does not seem to be important for commodities like paper. For other product categories, used material or components result in a discount. The greatest discount is for cell phones: presumably due to a mixture of personal and functional risk.

H4: Consumers' WTP a premium price for branded new products will be higher than for branded recycled/remanufactured products - partially supported.

Table 6 indicates that people are often willing to pay less for branded recycled/ remanufactured products than for branded new products.

Table 6 shows that consumers will pay more for a branded new product than for a branded greener product - except in the case of paper. It shows that, for a product that has been on the market for a long time and closely related to a benefit such as 'saving trees and forests', people will buy recycled paper rather than conventional paper and are indifferent to brand identity. In some cases - like paper - the buying choice is between green and new, and brand may not matter.

Tables 2, 3, 4, 5 and 6 show that respondents differ in their behavior for purchasing paper in terms of WTP for branded greener products, unbranded greener products, and branded new products. Additionally, for cell phones and automobile tires, respondents behave the same as for paper in terms of comparing branded greener products to unbranded greener products.

Table 4 Recycled/remanufactured products versus branded recycled/remanufactured products

\begin{tabular}{llll}
\hline Product category & Sample size & $\boldsymbol{T}$-statistics & Statistical significance \\
\hline Paper & 313 & -1.793 & $0.037^{*}$ \\
Camera & 316 & -0.802 & 0.21 \\
Cell phone & 321 & -1.91 & $0.028^{*}$ \\
Printer & 315 & -0.3 & 0.38 \\
Toner & 319 & -2.548 & $0.006^{*}$
\end{tabular}

Test of whether the difference between respondent values for each price is statistically and significantly different from zero. *Statistically significant at the $5 \%$ level. 
Table 5 Recycled/remanufactured products versus branded new products

\begin{tabular}{llll}
\hline Product category & Sample size & T-statistics & Statistical significance \\
\hline Paper & 315 & -1.57 & 0.059 \\
Camera & 316 & -5.2 & $0.001^{*}$ \\
Cell phone & 320 & -8.9 & $0.001^{*}$ \\
Printer & 315 & -7.7 & $0.001^{*}$ \\
Toner & 317 & -6.9 & $0.001^{*}$ \\
\hline
\end{tabular}

Test of whether the difference between respondent values for each price is statistically and significantly different from zero. * Statistically significant at the $5 \%$ level.

After comparing consumers' WTP for branded greener products, unbranded greener products, and branded new products, the relationship between perceived quality of branded recycled/remanufactured products and WTP was tested using regression analysis for each product (see Table 7).

There is a significant relation between perceived quality and WTP for branded recycled/remanufactured products. The effects of low strength, might be explained by other variables - such as perceived risk.

Finally, perceived risk was considered in relation with the branding's impact on WTP. Based on the measure perceived risk for recycled/remanufactured products, we ran means comparisons between WTP for recycled/remanufactured products and WTP for branded recycled/remanufactured products for those who perceive the risk of buying recycled/ remanufactured products to be high (perceived risk >2.5) and those who perceived it to be low (perceived risk $<2.5$ ). While respondents are unwilling to pay more for a recycled/ remanufactured product than for a conventional product, low-risk respondents are willing to pay a slightly higher price than their counterparts that consider the risk of these purchases to be higher. The difference in means for WTP increases slightly for highrisk respondents if brand is included ( $t=-3.55$ at the $1 \%$ level). However, this is not the case for respondents that perceive risk to be low.

\section{Discussion}

Insight into the impact of the product category, related functional risk, and brand name on consumers' WTP for greener (recycled and remanufactured) products is offered. The results indicate differences between product categories with respect to consumers' WTP for recycled/remanufactured versus new products. The effect of brand name on consumers' WTP for recycled/remanufactured versus new products varies in magnitude from product to product. Inclusion of brand name either has a significantly positive impact or has no difference in WTP.

Table 6 Branded new products versus branded recycled/remanufactured products

\begin{tabular}{llll}
\hline Product category & Sample size & $\boldsymbol{T}$-statistics & Statistical significance \\
\hline Paper & 312 & 1.09 & 0.138 \\
Camera & 315 & 4.37 & $0.001^{*}$ \\
Cell phone & 320 & 9.11 & $0.001^{*}$ \\
Printer & 313 & 8.64 & $0.001^{*}$ \\
Toner cartridge & 316 & 6.41 & $0.001^{*}$ \\
\hline
\end{tabular}

Test of whether the difference between respondent values for each price is statistically and significantly different from zero. *Statistically significant at the $5 \%$ level. 
Table 7 Regression results of WTP for branded recycled/remanufactured products on their perceived quality

\begin{tabular}{llll}
\hline Product & Perceived quality on WTP & & \\
\hline & Coefficient & R2 & Fvalue \\
Paper & $0.17^{* * *}$ & 0.039 & 10.918 \\
Toner & $0.206^{* * *}$ & 0.042 & 12.783 \\
Cell phone & $0.161^{* *}$ & 0.026 & 8.000 \\
Camera & $0.177^{* *}$ & 0.031 & 8.999 \\
Printer & n.s & - & - \\
\hline
\end{tabular}

Statistically significant at the $(* *) 5 \%$ level and $(* * *) 1 \%$ level.

\section{Contribution to theory}

The consumers' WTP premium prices for recycled/remanufactured products is clearly product specific. Recycled/remanufactured products do not have the same value as 'new' products. It is evident that some skepticism exists regarding many recycled/ remanufactured products. This attitude seems to be based on a perception that greener versions of some product categories are of lesser quality. Moreover, our results for the perceived quality of recycled/remanufactured products indicate that consumers expect some recycled/remanufactured product categories to be more acceptable than others: paper, toner cartridges, printers, cell phones, and then single-use cameras in terms of relative quality between new and remanufactured versions. This study supports earlier assumptions that a consumer's perceptions of quality of recycled/remanufactured products influences consumer WTP for these products.

Perceived functional risk of a product category influences consumers' WTP for new products versus products containing reused or recycled materials. Ferguson and Toktay [43] suggest that a reduced WTP for recycled/remanufactured products is influenced by a lower perceived quality of these products. Although levels of quality found in some greener products may exceed that of new products, the risk of a lack of quality or uncertain levels of quality is still present. However, one must consider each product category individually, as there are examples such as paper that are clearly not the case.

The respondents displayed a moderate level of familiarity with recycled products (mean $=2.58)$; this seems insufficient to enable them to assess the uncertainty and perceived risk associated with the recycled/remanufactured products' quality and performance. Again, recycled paper is the exception - a commonplace, low risk, commodity product. Elliot and Yannopoulou [53] suggest that when consumers are faced with a potential purchase involving a low level of perceived risk, familiarity will suffice for purchase this is the case for paper. But for other product categories considered here, there is a higher level of perceived risk and familiarity. Consumers are facing more 'unknowable' recycled/ remanufactured products. In such cases, confidence and/or trust are needed to counterbalance the perceived risk. Consequently, a brand name can reduce the risk by offering consumers assurance of quality and security. As perceived risk increases and price levels are high, brand names may offer comfort to consumers.

Tables 3 and 5 allow comparison of the attractiveness of greener (recycled and remanufactured), branded greener, and branded new products. Consumers' WTP differs depending on context. For example, the WTP for recycled and remanufactured products is influenced by brand name for paper, toner cartridges, and cell phones. With these 
categories, a brand offers some value or warranty increasing WTP. For cameras, printers, and tires, the brands have insufficient impact to significantly influence consumers' WTP for the recycled and remanufactured products. Although a strong brand acts as a proxy for quality [26], enabling consumers to better understand and accept uncertainty and risk [53], the brand did not impact consumers' WTP for cameras, printers, and tires. For product categories perceived as being of lower quality due to the inclusion of recycled or reused parts (thus higher perceived risk), the brand may not counterbalance the uncertainty. In summary, products with higher perceived risk are less influenced by the inclusion of a brand name - consumers are unwilling to pay more in these situations.

A lack of familiarity with specific brands (means range from 1.81 to 2.15 on a five-point Likert) may explain the lack of impact of brand for these product categories. Indeed, the use of different brand names - with different brand familiarity levels and brand equity could provide an additional insight. In order to affect WTP for remanufactured/recycled products, a strong brand with sufficient credibility is required. This relationship should be investigated further in future research.

Paper is a notable exception. Consumers express WTP more for recycled paper than for either branded recycled or even branded new paper. The value of recycling is greater than brand value for paper. While respondents were unfamiliar with the paper brand $($ mean $=2.09)$, the product category is familiar, predictable, and credible leading to a high WTP. Recycled paper is thus an interesting exception as respondents show a higher WTP for the recycled version than for branded and/or new paper.

\section{Implications to practice}

Marketers need to ensure and emphasize that the quality of recycled/remanufactured products is perceived as equal to traditional products - that is, decrease perceptions of high risk and low performance that may exist in the consumer's mind. This relation is directly linked to consumer familiarity with product categories. As recycled/remanufactured products become a more commonplace (like recycled paper), in the future, the associated ambiguity will decrease.

Information campaigns promoting recycling/remanufacturing could assist in establishing an 'as new' quality image for these products, which in turn would positively impact consumers' WTP. Besides quality, the environmental characteristics of recycled and remanufactured products need to be communicated. As in the absence of environmental information, consumers are willing to pay less for the remanufactured products than for its substitutes [21,22]. That is, environmentally conscious consumers aware of the environmental impacts of a conventional and a remanufactured product will select the remanufactured option offered by the OEM producing both new and remanufactured products, thereby benefiting from brand and reputation.

Next, companies should assess the potential impact of their brand on recycled/ remanufactured product versions. Brand may act as a warranty - overcoming perceived risk associated with a product containing recycled/remanufactured materials and components. This impact may or may not be greater than the difference in value between new and un-new products. In some cases - such as recycled paper - the brand has no apparent value. Therefore, companies should assess the impact on WTP of linking a brand name to 
recycled/remanufactured products. Companies should also consider launching a 'brand extension' - a recycled/remanufactured version of current product offerings. Two issues arise: (1) does a brand extension negatively or positively affect brand value and (2) will the extension negatively impact total profit through cannibalization of existing sales [15]. Both issues should be considered prior to launching a branded recycled/remanufactured product. Companies might offer a remanufactured version of their products in order to reach consumers who are at a lower price point but are looking for product functionality and brand name performance. For these consumers, the benefits related to the brand name may include the offer of extended or full warranty to support the remanufactured version of the product. As with conventional products, an extended or full product warranty clearly signals the confidence the company has in their products' quality. This is important for OEMs if there is consumer uncertainty regarding their remanufactured products' quality and performance.

Finally, investigating the role of branding for recycled/remanufactured products is of critical concern for the OEM in terms of both customer retention and profit maximization. Failure to offer a remanufactured product creates an opportunity in the marketplace that is often filled by a third party. The third party then benefits from the new markets that remanufactured products create and also captures the function-oriented part of the existing market currently satisfied by the new product [80]. If brand adds value to remanufactured products and the OEM is first to market, it is unlikely that third parties will enter the market as the need is fulfilled, and the OEM has a competitive advantage. If a third party is already in the market, the value offered by the brand may provide sufficient advantage for the OEM to enter and compete/reclaim a part of this market. Profit maximization is often supported by remanufacturing as production costs are lower. This is especially the case if price discount for remanufactured products is lowered through tactics such as branding.

\section{Limitations and future research}

A brand's importance differs depending on a product category. Sometimes this is very important in purchasing decisions related to recycled/remanufactured products. What exactly determines the importance of brand is an important question. Perceived risk and quality of the product appear to be important. Consumer assessment of quality and risk may or may not be counterbalanced by branding. A lack of brand value can be explained in part by the equity of a specific brand. Additional consideration of comparing the effects of brands having different levels of equity and their impact on consumers' WTP for branded greener (recycled/remanufactured) products is needed.

There is a tension between the 'lower' value of recycled/remanufactured parts of a product and the 'higher quality/value' association of a brand name. The balancing point of these two drivers is worth determining. In summary, for a recycled/remanufactured product, what does the consumer consider first: greeness or brand? Does a consumer first look for a greener product and then select an available brand, or does the consumer select a brand and then decide on a new or greener product? While Guide and Li [21] suggest that companies with well-established brand names should offer remanufactured versions of their products, it is unclear whether this is a call to compete for market share for greener products or to offer a low price point version of their existing products. 
Finally, the broader question of under what circumstances do brands offer substantial/ little value is an issue critical to firm marketing strategy. Additional brands with varying brand equity for a broader range of products should be considered in future studies. Indepth and analytical research is needed to assess the impact of brand/corporate identity on the WTP of products with reused or recycled content.

Subjects may declare a higher WTP to be seen as socially responsible than they would reveal by actual behavior. Consequently, it is likely that stated willingness to pay is higher than actual behavior. Future research should provide a better understanding of how stated preference and behavior differ and can be better calibrated.

\section{Conclusions}

The effect of branding on the WTP for greener (recycled/remanufactured) products is considered. This is important as failure to introduce recycled/remanufactured versions of a product creates the opportunity for third parties to compete against an OEM's existing market through an environmental differentiation strategy. This has occurred in several markets - including single-use cameras and toner cartridges - resulting in a loss of OEM market share. OEMs that sell recycled/remanufactured versions of their products increase corporate social responsibility (CSR) while profiting and protecting markets from the emergence of new competitors. Considering the impact of brand name on willingness to pay offers insights on the competitive advantage that OEMs have over third parties that compete via a 'greener' recycled/remanufactured version of the OEM's product. Brand tends to raise the value of recycled/remanufactured products according to stated willingness to pay. However, willingness to pay varies tremendously as a function of brand name and product category. Consequently, OEMs must consider the value of their brand for the products they offer. The approach used in this study can be utilized for this purpose. For theoreticians, the outstanding question is what type of risks do brands alleviate? For policy makers, what is the potential of education programs to reduce the uncertainty associated with products that have recycled/remanufactured content - and nullify the need for branding?

\section{Additional file}

Additional file 1: Survey utilized.

Competing interests

The authors declare that they have no competing interests.

Authors' contributions

$\mathrm{LH}$ and $\mathrm{JL}$ and developed the survey and were involved in data collection. Entry of data was conducted by a student. Statistical analysis was conducted by $\mathrm{JL}$ and $\mathrm{LH}$. Writing of paper and revising of paper was conducted by $\mathrm{LH}$ and $\mathrm{JL}$. All authors read and approved the final manuscript.

Acknowledgements

The assistance of Hervé Sibomana Bouchard in entering the surveys into a database is greatly appreciated. Thanks also goes to the Telfer School of Management for support through a SMRF grant, Canadian Foundation for Innovation for support for the Emerging Technology and Innovation Management Laboratory and the Power Corporation through support provided by the Power Corporation Professorship for the Management of Technological Enterprises.

Author details

${ }^{1}$ Telfer School of Management, University of Ottawa, 55 Laurier E, Ottawa K1N 6 N5, Ontario, Canada. ${ }^{2}$ Power Corporation for the Management of Technological Enterprises, University of Ottawa, 55 Laurier E, Ottawa K1N 6 N5, Ontario, Canada. 
References

1. Kilbourne, W, Pickett, G: How materialism affects environmental beliefs, concern, and environmentally responsible behavior. J Business Res 61(9), 885-893 (2007)

2. Prakash, A: Greening the Firm - The Politics of Corporate Environmentalism. Cambridge University Press, Cambridge (2000)

3. Schaefer, A, Crane, A: Addressing sustainability and consumption. J Macromarketing 25(1), 76-92 (2005)

4. Ewadinger, M, Mouw, S: Recycling creates jobs and boosts economy. Biocycle 46(10), 41-43 (2005)

5. Farrell Tucker, M: Becoming the world's coolest recycler. In Business 28(5), 14 (2006)

6. Jung, KS, Hwang, $\mathrm{H}$ : Competition and cooperation in a remanufacturing system with take-back requirement. J Intell Manuf 22(3), 427-433 (2011)

7. Shih, LH: Reverse logistics system planning for recycling electrical appliances and computers in Taiwan. Resour Conserv Recycling 32, 55-72 (2001)

8. European Union (EU 2003a): Directive 2002/96/EC of the European Parliament and of the Council of 27 January 2003 on waste electrical and electronic equipment (WEEE), Official Journal, L 037, 13/02/2003, pp. 24-39. European Union, Brussels (2003)

9. European Union (EU 2003b): Directive 2002/95/EC of the European Parliament and of the Council of 27 January 2003 on the restriction of the use of certain hazardous substances in electrical and electronic equipment, pp. 19-23. European Union, Brussels (2003). Official Journal, L 037, 13/02/2003

10. State of California: Electronic Waste Recycling Act of 2003 (SB 20) SHER. Statutes of 2003, California (2003)

11. Linton, JD, Klassen, R, Jayaraman, V: Sustainable supply chains: an introduction. J Oper Manage 25, 1075-1082 (2007)

12. Michaud, C, Llenena, D: Green consumer behavior: an exploratory analysis of willingness to pay for remanufactured products. Business Strategy Environ 20, 408-420 (2011)

13. Arndt, M: Cat sink its claws into services. Bus Week 3692(December 5), 56-59 (2005)

14. Linton, JD, Johnston, DA: A decision support system for the planning of remanufacturing at Nortel. Interfaces 30, 17-31 (2000)

15. Linton, JD: Assessing the economic rationality of remanufacturing products. J Product Innovation Manage 25, 287-302 (2008)

16. Finisterra Do Paco, A, Barata Raposo, ML, Filho, WL: Identifying the green consumer: a segmentation study. J Target Meas Anal Mark 17(1), 17-25 (2009)

17. Barquet, AP, Rozenfled, H, Forcellini, FA: An integrated approach to remanufacturing: model of a remanufacturing system. J Remanufacturing 3(1), 1-11 (2013). doi:10.1186/2210-4690-3-1

18. $\mathrm{Xu}, \mathrm{Y}$, Feng, W: Develop a cost model to evaluate the economic benefit of remanufacturing based on specific technique. J Remanufacturing 4(4), 1-12 (2014). doi:10.1186/2210-4690-4-4

19. Kinoti, M: Green marketing intervention strategies and sustainable development: a conceptual paper. Int J Business Soc Sci 2(23), 263-273 (2011)

20. Tsen, C, Phang, G, Hasan, H, Buncha, MR: Going green: a study of consumers' willingness to pay for green products in Kota Kinabalu. Int J Business Soc 7(2), 40-54 (2006)

21. Guide, VD, Li, J: The potential for cannibalization of new products sales by remanufactured products. Decision Sci 41(3), 547 (2010)

22. Hanss, D, Böhm, G: Sustainability seen from the perspective of consumers. Int J Consum Stud 36, 678-687 (2012)

23. Mobley, AS, Painter, TS, Untch, EM, Rao Unnava, $\mathrm{H}$ : Consumer evaluation of recycled products. Psychol Mark 12, 165-176 (1995)

24. Smith, VM, Keoleian, GA: The value of remanufactured engines: life-cycle environmental and economic perspectives. J Ind Ecol 8, 193-221 (2004)

25. Hamzaoui-Essoussi, L, Linton, JD: New or recycled products: how much are consumers willing to pay? J Consum Mark 27(5), 458-468 (2010)

26. Aaker, DA: Managing Brand Equity. The Free Press, New York (1991)

27. Erdem, T, Swait, J: Brand equity as a signalling phenomenon. J Consum Psychol 7(April), 131-157 (1998)

28. Agrawal, D: Effects of brand loyalty on advertising and trade promotions: a game theoretic analysis with empirical evidence. Mark Sci 15, 80-108 (1996)

29. Polonsky, M, Mintu, A: The future of environmental marketing: food for thought. In: Polonsky, M, Mintu, A (eds.) Environmental Marketing Strategies Practices, Theory and Research, pp. 389-391. Routledge, Oxford, UK (1997)

30. Ottman, J: What sustainability means to consumer product marketers. In: The Ottman Report on Environmental Marketing. (1998). available at: www.greemnarketing.com/articles/Ottman-Report.html

31. Charter, M, Peattie, D, Ottman, J, Polonsky, MJ: Marketing and Sustainability. The Centre for Business Relationships, Accountability, Sustainability and Society (BRASS), Cardiff (2002)

32. Barros, Al, Dekker, R, Scholten, V: A two-level network for recycling sand: a case study. European J Oper Res 110, 199-214 (1998)

33. Krikke, HR, Van Harlen, A, Schuur, PC: Business case OCE: reverse logistics network redesign for copiers. OR Spectrum 21, 381-409 (1999)

34. Zhang, T, Chu, J, Wang, X, Liu, X, Cui, P: Development pattern and enhancing systemof automotive components remanufacturing industry in China. Resour Conserv Recycling 55(6), 613-622 (2011)

35. Nasr, N: Real-world remanufacturing. Ind Engineer 43(6), 24 (2011)

36. Thorn, BK, Rogerson, P: Take it back. IIIE Solutions 34(4), 34-40 (2002)

37. Basgoze, $\mathrm{P}$, Tektas, O: Ethical perceptions and green buying behavior of consumers: a cross-national exploratory study. J Econ Behav Stud 4(8), 477-488 (2012)

38. Laroche, M, Bergeron, J, Barbaro-Forleo, G: Targeting consumers who are willing to pay more for environmentally friendly products. J Consum Mark 18(6), 503-520 (2001)

39. Pickett-Baker, J, Ozaki, R: Pro-environmental products: marketing influence on consumer purchase decision. J Consum Mark 25(5), 281-293 (2008)

40. Cason, TN, Gangadharan, L: Environmental labelling and incomplete consumer information in laboratory markets. J Environ Econ Manage 43, 113-114 (2001) 
41. Kirchhoff, S: Green business and blue angels: a model of voluntary overcompliance with asymmetric information. Environ Resour Econ 15(4), 403-420 (2000)

42. Miyake, M: Convergence theorems of willingness-to-pay and willingness-to-accept for non market goods. Soc Choice Welfare 34(4), 549-570 (2010)

43. Ferguson, ME, Toktay, LB: The effect of competition on recovery strategies. Prod Oper Manage 15(3), 351-368 (2006)

44. Hazen, BT, Overstreet, RE, Jones-Farmer, LA, Field, HS: The role of ambiguity tolerance in consumer perception of remanufactured products. Int J Prod Econ 135, 781-790 (2012)

45. Lund, R: Remanufacturing. Technol Rev 87, 18-23 (1984)

46. Mandrik, CA, Bao, Y: Exploring the concept and measurement of general risk aversion. In: Menon, G, Rao, AR (eds.) Advances in Consumer Research, 32nd edn, pp. 531-539. (2005)

47. Rousseau, DM, Sitkin, SB, Butt, RS, Camerer, C: Not so different after all: a cross-discipline view of trust. Acad Manage Rev 23(3), 393-404 (1998)

48. Mitchell, WW: Consumer perceived risk: conceptualisations and models. European J Mark 33(1/2), 163-195 (1999)

49. Matzler, K, Grabner-Kräuter, S, Bidmon, S: Risk aversion and brand loyalty: the mediating role of brand trust and brand affect. J Product Brand Manage 17(3), 154-162 (2008)

50. Germunden, HG: Perceived risk and information search: a systematic meta-analysis of the empirical evidence. Int J Res Mark 2, 79-100 (1985)

51. Agarwal, S, Teas, RK: Perceived value: mediating role of perceived risk. J Mark Theory Pract 9(4), 1-14 (2001)

52. Dodds, WB, Monroe, KB, Grewal, D: Effects of price, brand, and store information on buyers' product evaluations. J Mark Res 28(3), 307-319 (1991)

53. Elliot, R, Yannopoulou, N: The nature of trust in brands: a psychosocial model. European J Mark 41(9/10), 988-998 (2007)

54. Zeithaml, VA: Consumer perceptions of price, quality and value: a means-end model and synthesis of evidence. J Mar Sci 52(3), 2-22 (1988)

55. Bauer, RA: Consumer behavior as risk taking. In: Hancock, RS (ed.) Dynamic Marketing for a Changing World, Proceedings of the 43rd Conference of the American Marketing Association, pp. 389-398. (1960)

56. Kotler, P: Marketing Management, 9th edn. Prentice Hall, New Jersey (1997)

57. Han, CM: Country image: halo or summary construct? J Mark Res 26(May), 222-229 (1989)

58. Johansson, JK: Determinants and effects of the use of the 'Made In' labels. Int Mark Rev 6(January), 47-58 (1989)

59. Swait, J, Erdem, T: Brand effects on choice and choice set formation under uncertainty. Marketing Science 26(5), 679-697 (2007)

60. Steenkamp, J-BEM, Hofstede, F, Wedel, M: A cross-national investigation into the individual and national cultural antecedents of consumer innovativeness. J Mar Sci 63, 55-59 (1999)

61. Money, BR, Gilly, MC, Graham, JL: Explorations of national culture and word-of-mouth referral behaviour in the purchase of industrial services in the United States and Japan. J Mar Sci 62(October), 76-78 (1998)

62. Bearden, WO, Shimp, TA: The use of extrinsic cues to facilitate product adoption. J Mark Res 19, 229-239 (1982)

63. Fowler, GA: Green sales pitch isn't moving many products. Wall Street J 6, March (2002). B1 and B4

64. Herbig, P, Milewicz, J: The relationship of reputation and credibility to brand success. J Consum Mark 12, 5-10 (1995)

65. Erdem, T, Swait, J: Brand credibility and its role in brand choice and consideration. J Consum Res 31(1), 191-199 (2004)

66. Erdem, T, Keane, MP: Decision-making under uncertainty: capturing dynamic brand choice processes in turbulent consumer goods markets. Mark Sci 15(1), 1-2 (1996)

67. Eckert, C, Louviere, JJ, Islam, T: Seeing the forest despite the trees: brand effects on choice uncertainty. Int J Res Mark 29(3), 256-264 (2012)

68. Subramanian, R, Subramanyam, R: Key factors in the market for remanufactured products. Manuf Serv Oper Manage 14(2), 315-326 (2012)

69. Mooth, R: Winning a green innovation: room for growth in untapped markets. (2009). available at http://www. nielsen.com/us/en/insights/news/2009/winning-at-green-innovation-room-for-growth-in-untapped-markets.html accessed July 25, 2014

70. Aaker, DA, Keller, KL: Interpreting cross-cultural replications of brand extension research. Int J of Res in Marketing 10(1), 55-59 (1993)

71. El Korchi, A, Millet, D: Conditions of emergence of OEM's reverse supply chains. J Remanufacturing 4(3), 1-17 (2014). doi:10.1186/2210-4690-4-3

72. Park, C, Srinivasan, V: A survey-based method for measuring and understanding brand equity and its extendibility. J Mark Res 31(2), 271-288 (1994)

73. Sethuraman, R: A model of how discounting high-priced brands affects the sales of low-priced brands. J Mark Res 33, 399-409 (1996)

74. Tepper, $\mathrm{K}$ : The role of labeling processes in elderly consumers' responses to age segmentation cues. J Consum Res 20(March), 503-519 (1994)

75. Cho, CH, Lee, JG, Tharp, M: Different forced-exposure levels to banner advertisements. J Advert Res 41, 45-56 (2001)

76. Bohlen, G, Schlegelmilch, BB, Diamantopoulos, A: Measuring ecological concern: a multi-construct perspective. J Mark Manage 9(4), 415-430 (1993)

77. Cox, D, Cox, A: Communicating the consequences of early detection: the role of evidence and framing. J Mar Sci 65(July), 91-103 (2001)

78. Ko, Y, Hwang, H: Efficient operation policy in a closed-loop tire manufacturing system with EPR industry. Engineering Manage Syst 8(3), 162-170 (2009)

79. Linnanen, L: An Insider's Experiences with Environmental Entrepreneurship Making Ecopreneurs: Developing Sustainable Entrepreneurship, 2nd edn. Gowen Publishing Ltd, Farnham, England (2010)

80. Atasu, A, Guide Jr, VDR, Van Wassenhove, LN: So what if remanufacturing cannibalizes my new product sales? Calif Manage Rev 52(2), 56-76 (2010) 